\title{
Discovery of a supposed extinct settlement species made at Königsmühle in the Ore Mountains
}

\section{Petr Mikšíček}

\section{Envigogika 9(1) - Inspirations/ Inspirace}

Published/ Publikováno 30. 5. 2014

DOI: $10.14712 / 18023061.441$

\begin{abstract}
:
In one of my speeches on the Ore Mountains at the Green Network Conference in Dresden in 2011, I referred to the Ore Mountain region as a landscape full of footprints. Footprints left here by bygone generations of inhabitants as well as present-day footprints left by us. Footprints can be cast in plaster and preserved for future generations, or wiped out, hidden, erased from our memory. Both these approaches have been applied in the Ore Mountains. The preservation of these footprints clashes against the interests of land owners. The association DoKrajin, in which I work, tries to preserve the footprints, so I will gladly share with you a story of an ancient footprint that is on the brink of being wiped out.
\end{abstract}

\section{Key words:}

Ore Mountains; extinct settlement

\begin{abstract}
Abstrakt
V jednom ze svých př́spěvků o Krušných horách na konferenci Zelená sit́t v Drážd’anech v roce 2011 jsem pojmenoval Krušnohoří jako krajinu plnou stop. Stop, které zde zachovaly dávné generace obyvatele i ty současné stopy, které zanecháváme my. Stopy můžeme odlévat a zachovávat pro budoucí pokolení anebo je zametat, schovávat, vymazat z naší paměti. Oba dva př́stupy se $v$ Krušných horách uplatňují. Samotné nakládání se stopami naráží na zájmy majitelů pozemků. Sdružení DoKrajin, ve kterém působím, se snaží stopy zachovávat a tak vám rád představím př́běh jedné dávné stopy, která se nachází na bodu křehké rovnováhy mezi zachováním a zametením.
\end{abstract}

\section{Klíčová slova:}

Krušné hory, mizející sídla 


\section{Destruction of settlements in borderland areas}

About two million people left their homes in the former Sudeten against their will in the 1940s due to the outcomes of the Potsdam Conference. Their homes were either completely or inadequately resettled. Remote locations in mountain areas often remained totally abandoned. At the same time, however, such places represent a traditional model of settlement familiar in the rural environment, which was the determinant for the development of our landscape until roughly the beginning of the Industrial Revolution. Essentially, these places represent the model of the struggle of man with nature, in which the feedback mechanisms of coexistence between human culture and nature's maternal system were formed. That is one of the reasons why these places are important for our culture and landscape. In the 1950s, the Czechoslovak armed forces began a planned destruction of the remains of these settlements that were not repopulated after the eviction of the Germans. Heavy machinery arrived and all visible signs of such villages, hamlets and populated places disappeared, masked by grass and nettles. Heritage conservation authorities had to write off these valuable assets and handed over the remaining territories to nature protection bodies. Some 3000 villages, hamlets and populated places were wiped out in the Czech-German borderland. Some 17,000 houses were demolished. This genocide of small settlements affected Bohemia, Moravia and Silesia. According to period reports around 1960, we had "cleared away" the ruins in the borderland and afforested the remaining areas. It seemed that not a single specimen of this settlement type survived.

Until 2012, I lived under the impression that no more than a few ruins of walls, visible approximately up to shoulder height, were left by some mistake in the demolished Czech-German borderland. However, I made a unique discovery during my rambles in May 2012 - the forgotten hamlet of Königsmühle, which survived the genocide "by mistake". It was not demolished as part of the plan, nor was the village interior destroyed. In short, the hamlet just aged and decayed.

Between July 2011 and the end of August 2012, I planned with a few colleagues on how to enter the abandoned landscape in the former Königsmühle valley. We discussed what the site would tolerate and what it would not. We trod cautiously among the fauna, flora and history. The entire encounter was one big experiment with an unclear outcome. However, we all treated the process very cautiously and, subconsciously, most of the authors and organisers arrived at the same conclusion. We only managed to formulate that conclusion fourteen days after the exploratory work at Königsmühle was over. 


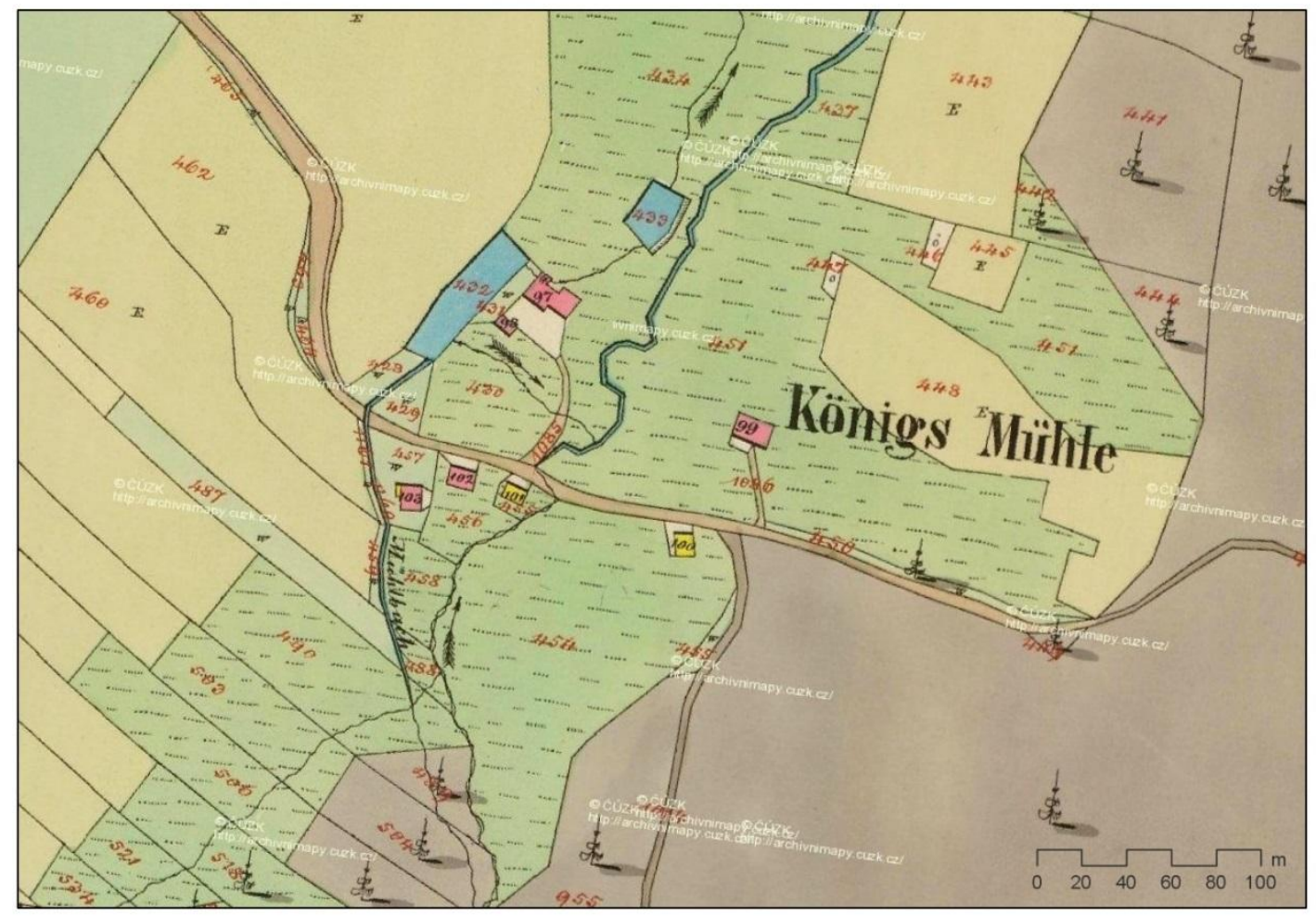

\section{What is the basis for calculating the heritage value of the extinct hamlet of Königsmühle?}

Königsmühle is fascinating in terms of cultural heritage. The genius loci, that is the atmosphere that the remains of the village evoke, is unique for both a lay person and the trained eye of the archaeologist. The well-preserved condition of the structures allows good legibility and interpretation of life in the valley even 70 years later. Typical building materials, remains of utility buildings and equipment can be found in the place. A water canal once used to bring water to a small reservoir is visible in the terrain. From the reservoir, the water ran back to the brook via a waterwheel. To be able to continue reading the landscape of the disappearing hamlet, however, its decay has to be halted. That can be done in many ways. Due to its location in an area of natural protection, the obvious option is to secure the perimeter walls in an environmentally sensitive way, use material that has fallen off to mend the building masonry, and remove the main natural destroyers from the cracks in the buildings. And why should we even think about preserving the ruins of Königsmühle? First of all, this site is a memorial to the era of destruction of settlements in the 1950s. So far, in the whole Czech-German borderland, there is no place of commemoration or memorial to the 3000 destroyed villages situated on an original site. Most of the sites are inconvenient for that purpose. Either nothing at all is left standing or the entire village interior has been devoured by thick tree seedage, which would hardly be attractive to visitors. In Königsmühle, a set of valuable historical buildings, an open and passable terrain and an aesthetic experience of the surrounding landscape are all combined.

It is more than likely that, unless the buildings are conserved, the site itself will disappear within 20 years. It is not only a matter of the quasi-natural valley but also a well-preserved example of an extinct settlement in a mountain valley. The former hamlet 
itself is a unique site of its kind, where landscape, historical and natural values intersect. The surrounding meadows also feature relics of the era of a booming mining industry in the Ore Mountains.

\section{Die Königsmühle in Großbildaufnahme}

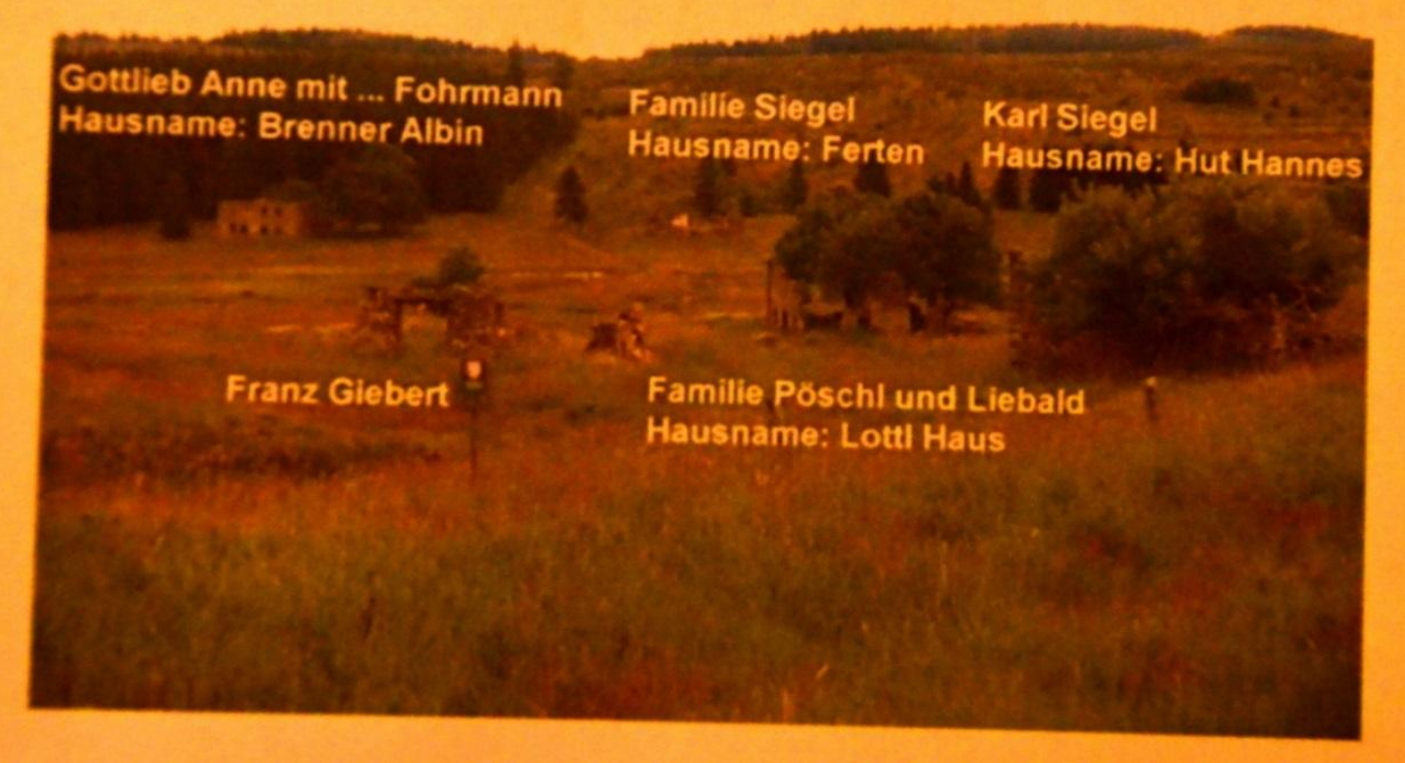

Königsmühle is composed of the remnants of six homesteads scattered in a shallow valley. Five of the buildings were houses for living, namely the Fohrmann family (rear left), the Siegel family (rear centre), the Giebert family (centre left), the Pöschl family (centre right), and another family by the name of Siegel (rear right). The other two buildings, which are not shown in the picture (Figure 1) are situated to the left of the hamlet, were probably mills. Ruins of some walls and a cellar of the first mill can still be seen below the reservoir.

Königsmühle may be a place where top-down heritage conservation efforts (methodologies, designating it as a cultural heritage site, legal support, etc.) and bottomup conservation efforts (presentation of value of the site to local decision-makers and those who visit the area) can meet.

\section{What sort of site is Königsmühle in terms of heritage conservation?}

A slow succession site - the terrain is not overgrown and only decaying slowly; nature is still in a kind of balance with human labour. The question is in what stage do we wish to halt and conserve the buildings' decay? Which component is the most important?

A site without forcible destruction - the hamlet has not seen any bulldozing; it features original terrain and bumpiness that improves the legibility of the site. The intact farm track coming from the village of Háj is another major element of local life. It is a natural as well as cultural sight in itself. 
A legible site - the advantage of the site is the considerable intelligibility of its relics (layout and positions of the buildings, hydraulic works, roads as well as details: a bricked-in niche, hinges, etc.). In short, it is possible to easily determine the layout and remains; count the numbers of window columns, entrances etc.

The site could be used as an "experimental site" for examining the application of various methods of historic structure conservation and their long-term effects. Again, this activity would have to proceed in compliance with nature protection. Alternatively, the site could be used as a training ground for students or heritage conservation workers - thanks to the stage of preservation versus the stage of destruction, the functions of buildings, rooms, the settlement as a whole, etc., can be determined based on the extant building remnants.

Königsmühle could also be supported by the development of information boards, leaflets and, above all, organisation of commented tours with various focuses: history, construction history, nature, art, or a combination of all of them.

Here again the only question is how many people it is appropriate to bring to the site. Here we pause for a moment of self-reflection on the necessity of peoples' re-entry of a site that others once decided to leave. Was it an irrevocable decision, or was it not?

\section{How to treat Königsmühle in the future?}

We spent over a year pondering Königsmühle and its existence, what it has to tell us and what we have to tell it. The reason is that it is a kind of apparition, an extinct species that has survived by mistake. An unwanted species. What should we do with it? Should we revive it? Forget about it? Demolish it forthwith? All of that was reflected in our works and conversations at the turn of August and September 2012 and again in 2013, when we organised the Königsmühle Land and Art Convergence in conjunction with DoKrajin association.

From the long-term perspective, the site has turned out to be unique and highly impressive. Generally speaking, the discovery of a seemingly extinct settlement type is a sensation in itself. Königsmühle was supposed to be demolished and grassed over long ago. It is a miracle that we have in the landscape something that the authorities had planned to demolish in order to prevent us from remembering the story of the first half of the $20^{\text {th }}$ century. As you might have suspected, official law cannot be applied to something that was supposed to be gone long ago. That is why the ruins of Königsmühle have support in neither heritage conservation nor nature conservation. The only notion from the human realm that applies to the ruins of Königsmühle is genius loci. The spirit of the place. How symptomatic. In most places, it is but the spirit - a gust of wind. But Königsmühle is still alive. At the same time, this intangible notion suggests the words memory, legacy: a remembrance of the people who lived here and struggled with the natural environment for every inch of land.

Although I am experiencing an unprecedented dilemma internally whether I regret more the ruins doomed to extinction or the splendid, vivid natural scenery, benefiting from the remoteness - which will be reduced by people's interest of course, the force of the act of disappearing, that which has a limited "lifetime", has perhaps gained the upper hand in me. I am really more of a culturologist than a natural scientist. Even though I am an atheist, I still feel the need for the dispensation of last rites and confession. 


\section{Preservation of footprints in the landscape from the land owner's perspective}

A rather inconspicuous, but all the more momentous event took place in Háj and at Königsmühle at high noon of 16 November 2013. On this beautiful day full of sunshine and bashful fog, the carpenter René Vaněček from Volyně, assisted by about ten volunteers, installed two outdoor panels on the history of the extinct villages and, above all, about Königsmühle itself. At the entrance to the former hamlet at the end of the farm track, you can thus study not only the existing information about the natural values of the Königův mlýn nature reserve, but also about the history of the buildings that have survived here. The information boards were made thanks to funding support from Objective 3 and the Czech-German Future Fund.

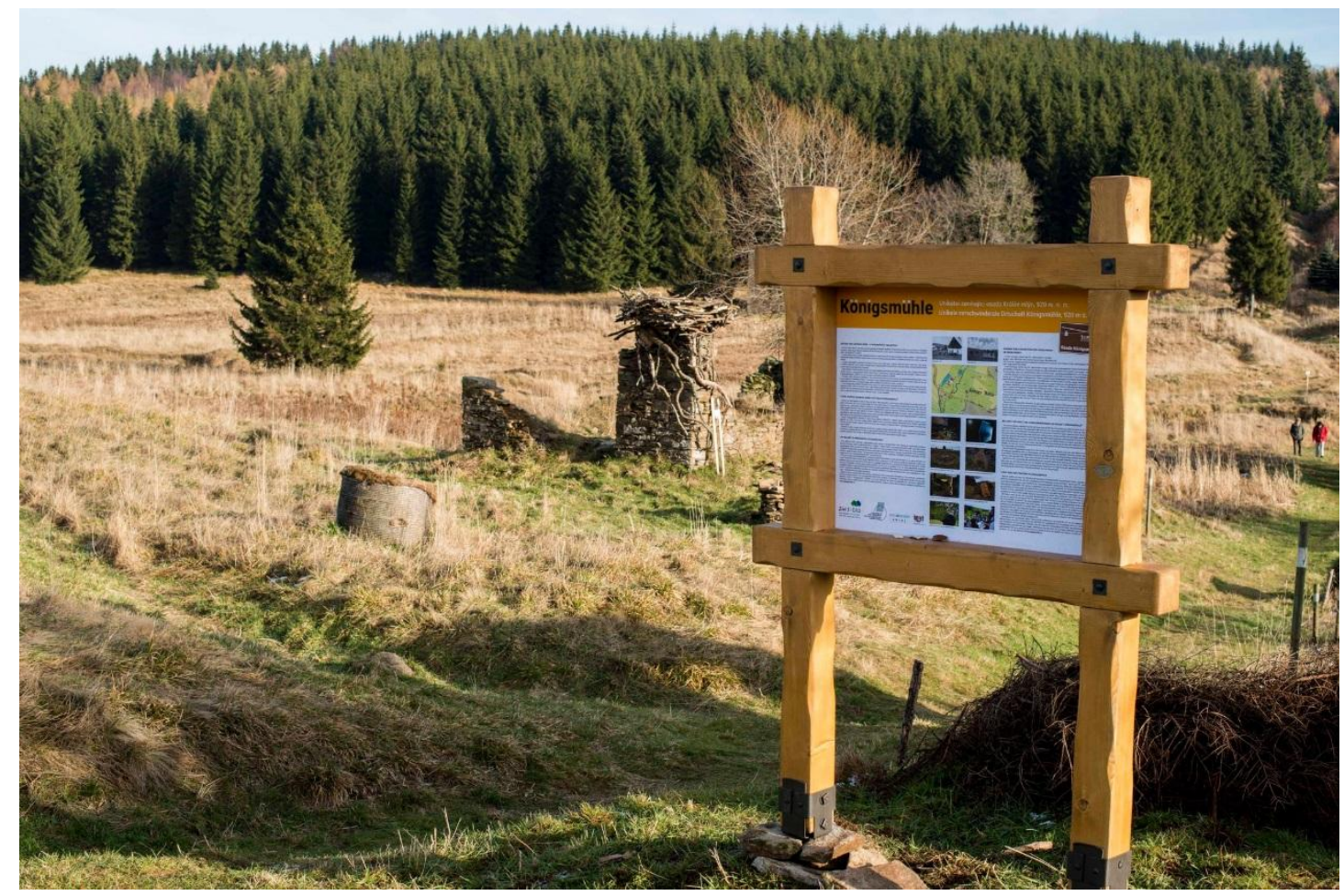

The installation of the panels is a formal confirmation of the values hidden in the Černá voda valley. It would have been impossible, however, without initiating cooperation with the land owner - Lesy ČR, a.s.

The cooperation between Lesy ČR, a.s., DoKrajin association, which organises the conservation work on the ruins of Königsmühle, the municipality of Loučná pod Klínovcem, and the Ústí Region Environmental Department took shape at a meeting that preceded the installation.

Based on an agreement to cooperate, it will be possible to maintain the remnants of the cultural landscape at Königsmühle on the land owned by Lesy ČR, a.s. An important part of the agreement was shifting the date of the Land and Art Convergence to early August and the quietening of the evening event in the valley itself. In exchange for this compromise Lesy ČR, a.s. offered to assist with landscape management. This involves maintenance of a footbridge over the Černá voda stream and construction of a small tourist shelter behind a former farmstead building. The prevention of decay of the perimeter walls of the main building of the former hamlet will be possible at our own risk 
by enveloping the tops of the walls with a wooden cladding and partially bonding the walls with vertical wooden poles inside the building. We will collaborate with the National Heritage Institute in Ústí nad Labem to plot the buildings on maps.

Another possible activity for 2014 and 2015 may be the restoration of the infrastructure of the local cultural landscape. This involves primarily the renewal of a former water moat and mill pond, which is still clearly visible in the landscape. Preparatory works for the next week-long summer convergence at Königsmühle in 2014 will proceed towards that end.

The acknowledgement of the existence of the hamlet of Königsmühle is a point where we have not found agreement with the land owner. It does not exist on any maps and the ruins are not marked at all in the cadastre map. Lesy ČR, a.s. does not wish to formalise the existence of Königsmühle by including it in the maps. It will therefore probably not occur on any maps because that would oblige the owner to take care of the buildings. For this reason we cannot even think of raising any funds for the conservation and potential revival of the buildings - they will probably never be formalised. That by itself reflects the policy of wiping out footprints. But who wants to wipe out the footprints in the landscape?

In the course of the three years for which we have been active at Königsmühle, we have seen attempts to wipe out footprints quite frequently. After the first Land Art Convergence, an unknown "artist" devastated the works of art and the tourist amenities that we had made. Thus, the reminiscences of the former inhabitants of the hamlet, symbolised by 53 poles hammered in the ground with white ribbons, disappeared from the landscape after the first year. Works that used not only natural materials disappeared as well. So did the poems inspired by the place branded on wooden planks. We can only conjecture whether they ended up in a stove or hung on a wall, continuing to impress with their poetry the simple soul of a local self-proclaimed creator of the landscape status quo.

The question arises as to whether our activity is presumptuously self-appionted. We do not think so. We have the consent of the local Meluzína association, the consent of the municipality of Loučná pod Klínovcem, and currently also of the land owner. Gamekeepers and Czech nationalists are groups that have never accepted the activities at Königsmühle. Some local people and weekenders are not happy with a lot more people coming to Königsmühle. It is no longer the romantic and desolate place that only they knew about. In the last two years, Königsmühle has twice been used as a setting for shooting two feature films, and an outdoor film for bikers, and as a place with a strong genius loci where clients of so-called ecopsychology are brought. Königsmühle has made it to ČT1, the main national news show and a feature documentary was made about it. It is often visited by both former inhabitants and artists, who bring their works of art with them. Simple structures - benches, tables, breast walls - are built in the landscape using ubiquitous loose stones from the walls.

According to local people's observations, Königsmühle has become an appreciated destination for visitors for numerous reasons. Königsmühle is becoming the coveted consilience of natural science, human sciences and arts.

It can be said that in the last three years we have managed to clean, highlight and make publicly accessible this forgotten footprint, unique in the entire landscape of the Czech-German borderland. However, the question remains whether we will preserve it for future generations. In this and similar cases, the achievements are based on the enthusiasm of a limited group of people with whom the plaster-casting and preservation of footprints stands or falls. 

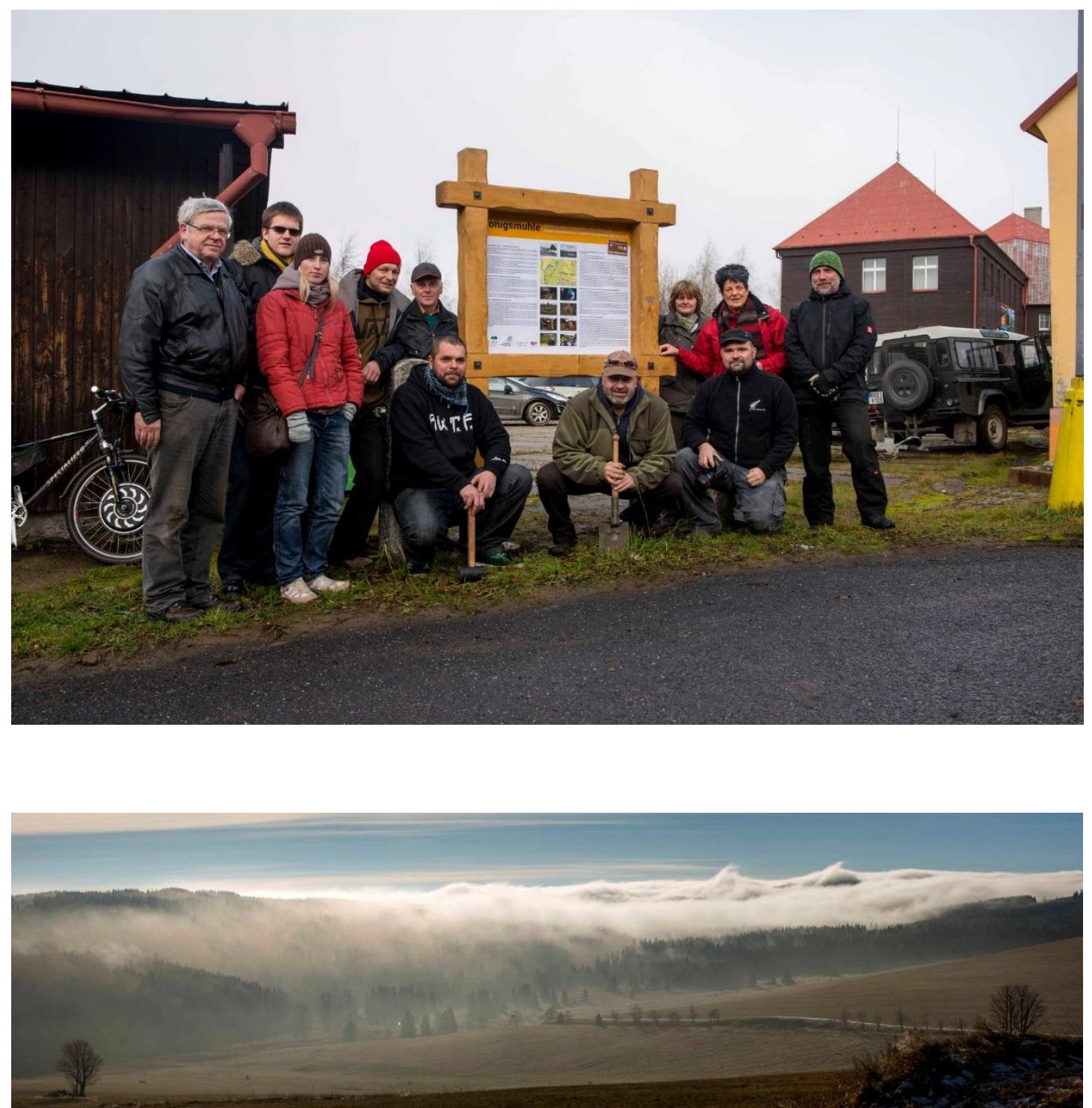

On behalf of DoKrajin association,

Petr Mikšíček

www.znkr.cz

$\underline{\text { www.konigsmuhle.cz }}$

www.dokrajin.cz

\section{Petr Mikšíček}

Graduated from the Philosophical Faculty Charles Univesity in Prague. In 1998 founded with his friends civic association Antikomplex concerned with history and present of the Czech-German borderland. Author of numerous books, films and photography exhibitions.

\section{e-mail: petrmiksicek@gmail.com}

